29 maps and figs. 1961. Prico 2.50 dollars). These important gold deposits occur in the form of quartz lenses both in chlorite-schist shear zones cutting pre-Cambrian greenstones and in highly folded and contorted pre-Cambrian sedimentary rocks. Extensive chemical evidence is presented in support of the thesis that the elements present in the ore bodies came from the country rocks, whence they were concentrated into dilatant zones during metamorphism. It is claimed that both gold and silver are constituents of all rocks in the district, and that, since they were originally present in amounts sufficient to yield any of the concentrations forming ore deposits, it is unnecessary to call on magmatic hydrothermal solutions as a source for the two elements. These views are a reversion to the lateral secretion theories of von Sandberger expressed in his Untersuchungen über Erzgänge nearly eighty years ago, and it seems likely that Dr. Boyle's well-documented revival of such concepts will stimulate considerable discussion by other economic geologists.

\section{Surface Activity}

AN attractive 21-page booklot, entitled Surface Activity, by R. J. Taylor of Unilever Resoarch Division (A Unilever Educational Booklet-Advanced Series. London: Unilever, Ltd., 1961) is the first in the series of educational booklets which Unilever is publishing for sixth-form pupils to use as a supplemont to school text-books. A detailed explanation is given, with the help of clear diagrams and illustrations in colour, of surface activity and some of its important applications, including water conservation, emulsification, detergency, flotation and foams. The treatment is intended to be complementary to that of surfaco tension as doalt with in school text-books. In the theoretical section dealing with adhesion, contact angle, spreading and bubbles, the four measurablo quantities-surface tension, interfacial tension, contact angle and surface pressure-are mentioned, and, in the second section of the booklot, experimental methods for the measuremont of these quantities are doscribed. Finally, various applications of surface activity are discussed.

\section{Individual Variation in Nutrition}

A symposrum on "Individual Variation", organized by the Nutrition Society, is to bo held at the National Institute for Medical Research, London, during March 17. The chairman will be Prof. B. S. Platt, and topics under discussion will include: nutritional individuality (Dr. E. M. Widdowson); normal variations in blood constituents (Dr. I. D. P. Wootton); individual variations in the lipid trans port system (Dr. R. E. Olson); some aspects of physical and physiological individual variation in growth and development (Dr. R. W. McCammon); variations in human energy-intake and expenditure in Great Britain (Mr. J. M. Harries, Mrs. E. A. Hobson and Miss D. F. Hollingsworth); genetic variation in the nutrition of Drosophila (Dr. F, W. Robertson). Further information can be obtained from Miss D. F. Hollingsworth, Ministry of Agriculture, Fisheries and Food, Great Westminster House, Horseferry Road, London, S.W.1.

\section{Cambridge University Library :}

Gowland Hopkins Centenary

Dr. Malcolm Dixon, Dr. Barbara E. Holmes and Dr. Joseph Needham write that: "In commomoration of the centenary of the birth of Sir Froderick Gowland
Hopkins, a collection of papers, etc., concerning his life and work is being formed in the Cambridge University Library. We should be very grateful if anyone having in their possession manuscript or typescript letters of his, or letters addressed to him, or any other rolevant documents, would send them to us for deposition in the collection as such or for copying and return, addressed to Dr. Joseph Needham, at Caius College, Cambridge".

\section{Announcements}

Dr. EDWARD R. Weidlern, former president of the Mellon Institute, Pittsburgh, has been awarded the William Procter Prize for scientific achievement by the Scientific Research Society of America for his work in industrial research.

The Centre National de la Rechorche Scientifique, Paris, is offering a prize of 10,000 N.F. for the best solution, received before October 1 , to the problem of documenting the enormous amount of scientific material at present being published. Further information can be obtained from the Contre National de la Recherche Scientifique, 15 Quai Anatole France, Paris $7 e$.

A symposium on "Ferro Alloy Industry in India" is to be held at the National Metallurgical Laboratory, Jamshodpur, during February 12-15. Further information can be obtained from the Director, National Metallurgical Laboratory, Jamshedpur, India.

A symrosium on "Fquatorial Geophysies", sponsored by the Interamerican Union of Scientific Radio together with the Interamerican Union of Geodesy and Geophysies, is to be arranged by the Instituto Geofisico dol Peru (formerly the Huancayo Geophysical Institute) in Lima during March 19-23. Further information can be obtained from the Instituto Geofisico del Peru, Apartado 3747, Lima.

'THe thirteenth Pittsburgh conferenco on "Analytical Chemistry and Applied Spectroscopy" is to be held in Pittsburgh during March 5-9. The progranme will include the symposia on: Raman spectroscopy; vacuum spectroscopy; gas chromatography; spectroscopic studies of polymors; chemical analysis of metals. 'Thero will also be an exhibition of new analytical instruments. Further information can bo obtained from the programme chairman, Dr. C. F. Glick, Applied Research Laboratory, United States Steel Corporation, Monroeville, Pennsylvania.

A symposium entitled "Basic Problems in Neoplastic Disease", sponsored by Columbia University College of Physicians and Surgeons, is to be held during March 12-14, to commemorate the fiftieth anniversary of the Institute of Cancer Rosearch at the University, and the tenth anniversary of the Francis Delafield Hospital. The subjects under discussion will include: nucleic acid structure and synthesis; viral and genetic studies; protein synthesis; antibody structure and function. Further information can be obtained from the Institute of Cancer Research, Columbia University College of Physicians and Surgeons, 630 West 168th Street, New York 32, N.Y.

Erratum. The title of the communication by Prof. J. M. Wiamo et al. in Nature of January 6, p. 70, should read: "Mutation of Bacillus subtilis affecting the Aconitase and the Dicarboxylic Acid Specific Transport", and not as that given. 